\title{
Chapter 6 \\ Education of Roma and Educational \\ Resilience in Hungary
}

\section{Z. Attila Papp and Eszter Neumann}

\begin{abstract}
Originally, the concept of resilience refers to one's capacity to cope with unexpected shocks and unpredictable situations. Originating from ecological theories, the approach has gained ground in social sciences. In the context of education, the concept has been applied to explain how disadvantaged students can overcome structural constraints and become educationally successful and socially mobile (Werner, E. E., Vulnerable but invincible: a longitudinal study of resilient children and youth. McGraw-Hill, New York, 1982; Masten A. S., American Psychologist 56: 227-238, 2001; Reid, R., Botterrill L. C., Australian Journal of Public Administration 72:31-40, 2013; Máté, D., Erdélyi Társadalom 13:43-55, 2015).

This paper is based on the analysis of the Hungarian National Assessment of Basic Competences (NABC) database which has been conducted annually since 2001. We created a typology of school resilience based on the schools' social and ethnic profile as well as their performance indicators. We defined those schools resilient which over perform others with similar social intake, and we also identified irresilient schools which underperform others with similar social intake. The school types were created by correlating the socio-economic status index (SES) and school performance.

Since the NABC database provides us with data on the estimated rate of Roma students in each school, it is possible to take into account the schools' ethnic intake in the analysis of resilience. We conducted statistical analyses to compare the performance of resilient and irresilient schools in the light of the ratio of Roma students. Finally, we seek answers to the question whether ethnic segregation correlates with school achievement in Hungary. We could identify some crucial
\end{abstract}

\footnotetext{
Z. Attila Papp $(\bowtie)$

Hungarian Academy of Sciences, Center for Social Sciences Institute for Minority Studies, Budapest, Hungary

Mickolc University, Institute for Applied Social Sciences, Miskolc, Hungary

e-mail: pappz.attila@tk.mta.hu

E. Neumann

Hungarian Academy of Sciences, Center for Social Sciences Institute for Minority Studies,

Budapest, Hungary

e-mail: neumann.eszter@tk.mta.hu
} 
institutional factors contributing to resilience (or school success) in the case of schools with relatively high proportion of Roma students.

Keywords Roma education $\cdot$ Educational resilience $\cdot$ School success $\cdot$ Hungary

\section{Introduction}

It is common sense to say that the school is not an "island" its surrounding social relations and organizational environment. Therefore, it seems relevant to explore the ways in which schools and the communities they serve interact and mutually form each other. Of course, besides the local context, school level system specific, student and classroom characteristics are playing a crucial role in schools' everyday life. (Creemers et al. 2013).

The factors behind school success and underperformance are widely discussed in literature. International school effectiveness research (OECD 2010a, b; Mourshed et al. 2010; Teddlie and Reynolds 2000) suggests that a well-established culture of data-based provision as well as formalized and institutionalized procedures can effectively raise school performance. The sociology of education has studied social redistribution processes within the sub-system of education for long (Jencks et al. 1972; Clotfelter 2006). From the late 1970s, a new research trend appeared in the school effectiveness literature which paid particular attention to students' social background (Sammons and Reynolds 1997; Teddlie and Reynolds 2000). These studies define effective schools by their significant added pedagogical value in comparison to schools with similar socio-economic and socio-cultural background. Such researches pay particular focus to the schools' impact on student attainment, development and future educational trajectories (Sammons 2007; Scheerens and Bosker 1997). Authors of these studies had argued that good leadership, achievement oriented staff communicating high expectations towards students, coherent and consensual institutional culture, high quality curriculum, safe and appropriate atmosphere, coherent assessment and feedback systems, high level of parent involvement, good classroom atmosphere, autonomous learning opportunities, and differentiated teaching are among the most important institutional, organizational and professional features of effective schools. School effectiveness research also identified the organizational changes necessary to increase student performance (Sammons 2007).

\footnotetext{
${ }^{1}$ The current analysis is based on research projects financed by the National Research, Development and Innovation Office, (research id: NKFIH 120400, The school is not an island) and the University of Miskolc (Creative Region-Excellence Research Project). The members of the research team are: Margit Feischmidt, Ernố Kállai, Zsuzsanna Vidra, Szilvia Németh, Eszter Neumann, Csilla Zsigmond, János Zolnay, Ágnes Patakfalvy-Czirják, Erzsébet Csereklye, and Katalin Kovács. Some team members have also contributed to some parts of this paper. Special thanks to Csilla Zsigmond (Hungarian Academy of Sciences) and Kinga Szabó-Tóth (University of Miskolc).
} 
In the Hungarian context, we are particularly interested in the situation of schools with a significant Roma intake. The underachievement or failure of disadvantaged and/or Roma students both stem from structural reasons (such as school and residential segregation and child poverty) and more subtle aspects such as the lack of emphasis on inclusivity in school cultures (Radó 1997; Szalai and Schiff 2014). However, the local interethnic conflict potential, that is the lack of successful interactions and role models which would be essential for Roma children to develop positive learner identities and to raise their educational aspirations, have not been systematically analysed in Hungary so far. Moreover, it would be important to analyse the emotional and other costs of the educational success and mobility of Roma young people and their remedies, as certain studies emphasize that upward social mobility causes identity problems and conflicts which can be transcended by assimilation or the emergence of a particular minority culture of mobility (Tóth 2008; Durst et al. 2016).

\section{The Hungarian Educational and Public Policy Context}

In Hungary-similarly to some other European countries-research and policy regarding Roma education face a major challenge, namely the lack of officially collected data on ethnicity. The Hungarian educational administration stopped to collect statistical data on Roma ethnic origin since the 1992/1993 school year. In the ensuing decades, however, the statistical departments of the former Ministry of Culture (later the Ministry of Education and Public Education) created a so-called ethnic database which was based on annual teacher evaluations in school surveys regarding the Roma pupils' progress. This database reveals that the total number of Roma pupils grew from 60,000 in the late 1960 s to almost 75,000 in the early 1990 s (Kertesi 2005). Data is not available on the student population dynamics in the 1990s. However, from the early 2000s, the survey accompanying the Hungarian National Assessment of Basic Competences (NABC) comprises a question regarding the pupils' ethnic origin within the question block on the schools' social composition. ${ }^{2}$ Of course this is an estimate based on local 'knowledge', but its enormous advantage is that, in principle, it is accessible at all school premises (it should be noted that not all school premises have answered this question, the rate of missing cases is $5-10 \%$ per year).

Based on NABC database, one may get a snapshot on the estimated rate of Roma pupils within the Hungarian education system. Furthermore, it is possible to assess how the estimated rate of Roma pupils, school performance, and the external and internal conditions of the schools correlate.

\footnotetext{
${ }^{2}$ The question is formulated as follows: "In your opinion, at your school site, what is the PER CENTAGE RATIO of those elementary school students who can be characterised by the following features? ... Of Roma origin...?"
} 


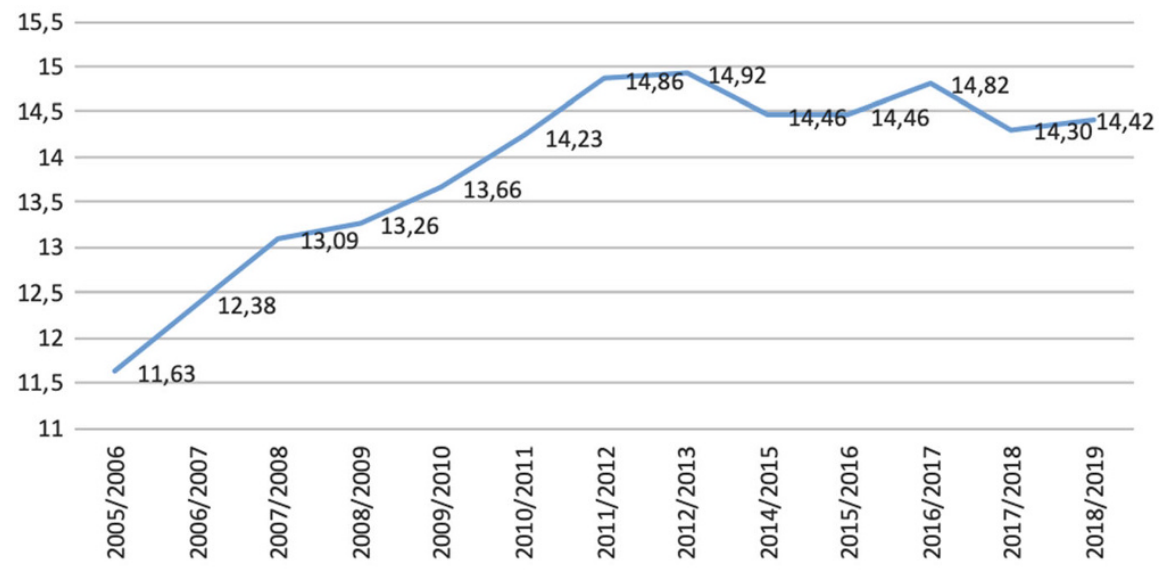

Fig. 6.1 Estimated number of Roma pupils in the elementary schools (Source: own calculation from database of NCM)

It can be stated that in the long run the proportion of Roma pupils and the absolute values exhibit an increasing, while the overall elementary school population shows a decreasing trend. Currently, the proportion of Roma pupils is around $14-15 \%$ in Hungarian elementary schools (see Fig. 6.1). Importantly, a North-South slope characterizes the country: that is a higher rate of Roma students in the northern regions and a lower one in the southern regions. Long-term data collection revealed that the pace of growth is higher in those northern counties where the rate of Roma pupils was higher earlier. This foreshadows further increasing regional disparities. According to micro-regional/school district data, the estimated rate of Roma pupils is already above $50 \%$ at several locations.

Using the NABC databases, we could identify nearly 300 'ghetto schools' (with a Roma rate above 50\%, see Havas 2008) among school premises/locations over the last years, which are referred to as. Nearly half of these premises are located in Northern Hungary and three-quarters operate in villages. This also indicates that higher Roma rates, segregation and corresponding pedagogical challenges mainly characterize schools located in smaller settlements of the northern counties of the country (Papp 2011; Feischmidt 2013; Kovács 2012; Vidra 2012; Virág 2012).

One can establish an inverse linkage between the results of the NABC tests and the estimated rate of Roma pupils: the higher the ratio of Roma pupils, the lower the average of the aggregated test results at the schools. However, this correlation can easily lead us to false conclusions. If one takes into account the so-called familybackground index of the school at the statistical interpretation, it will become evident that at a systemic level, low performance is not correlated to ethnicity, but to the students' social background. Differences related to the social and family background override the rate of Roma in the school. Thus, schools with a higher rate of Roma pupils do not usually perform weakly because they educate Roma children, but 
Table 6.1 List of public policy paradigms (1993-2016)

\begin{tabular}{|c|c|c|}
\hline Period & Paradigm & Main Public Policy Acts \\
\hline 1993-2002 & $\begin{array}{l}\text { Cultural, essentialist } \\
\text { paradigm }\end{array}$ & $\begin{array}{l}\text { Law on Minorities (1993) } \\
\text { Minority education policy - improvement } \\
\text { of social and ethnic disadvantages } \\
\text { End of } 1990 \text { 's: review of the essentialist } \\
\text { paradigm }\end{array}$ \\
\hline 2002-2005 & Desegregation & $\begin{array}{l}\text { Antidiscrimination } \\
\text { Prohibitions and financial incentives } \\
\text { National Education Integration Network } \\
\text { (NEIN) } \\
\text { Skill development and integration } \\
\text { preparation, creating legal categories: social } \\
\text { disadvantaged student and multiple social } \\
\text { disadvantaged student }\end{array}$ \\
\hline 2004-2007 & Integration & $\begin{array}{l}\text { Extension of Integrational Pedagogical } \\
\text { System (IPS) }\end{array}$ \\
\hline 2007-2010 & $\begin{array}{l}\text { Equal Opportunities, } \\
\text { Mainstreaming }\end{array}$ & $\begin{array}{l}\text { Equal Opportunities } \\
\text { Attempt to eliminate territorial educational } \\
\text { segregation }\end{array}$ \\
\hline 2010 - & Inclusion & $\begin{array}{l}\text { Act CXC of } 2011 \text { on National Public } \\
\text { Education, centralization } \\
\text { NATIONAL SOCIAL INCLUSION } \\
\text { STRATEGY - Extreme Poverty, Child } \\
\text { Poverty, The Roma - (2011-2020) }\end{array}$ \\
\hline
\end{tabular}

because these pupils have a less supportive learning environment and more disadvantaged family conditions (Kertesi and Kézdi 2011; Papp 2011, 2013).

The increasing involvement and efficiency of Roma pupils in schools have continuously been the target of educational policy interventions, and the question of teaching Roma and non-Roma students together or separately, i.e. in integrated or in segregated classrooms, has re-emerged over and over again. Summing up the various public policy paradigms (Table 6.1), one can state that free school choice codified 4 years before the regime change had effectively strengthened segregation trends, as more affluent and higher educated parents were more motivated to search and find schools with children of similar backgrounds and, consequently, where the rate of Roma pupils was lower due to structural factors. The period of 1993-2002 is 
interpreted by scholars as a "cultural, essentialist paradigm" (Neumann 2013) which was dominated by the view that the education of Roma children would be more successful by transferring minority culture, and therefore targeted classes and lessons should be organized for them. Subsequently, governments in power after 2002 focused on desegregation and launched several interventions dedicated to desegregation after 2004. This policy paradigm emphasized that pupils have to be educated in an integrated way, i.e. mixed Roma and non-Roma classes should be organized, and supportive experts argued that from this arrangement Roma pupils would only profit (will become more successful), and non-Roma pupils would not be harmed either (Kézdi and Surányi 2009). However, although schools knew what the 'policy direction' was, it did not automatically mean that prejudice against Roma declined and the Pygmalion effect typically prevailed in the daily practice of the schools. Some sort of double language developed: an official, politically correct 'project language' and an informal 'language below', and the two often being contradictory, an inconsistent spectrum of arguments characterized the schools (Erôs 2012; Németh and Papp 2006; Neumann 2013).

Since 2010, Hungary has a new government which rejected the desegregation paradigm and started to frame its policies in a catching-up narrative arguing that those lagging behind should be taught separately. In the post-2010 period, the basic motive has been responsibilization, it has been argued that the Roma should also show their 'own contribution' in catching up to the majority, and educational officials underlined the expectation to catch up instead of being caught up. The new National Public Education Act was adopted in 2011 brought a high degree of centralization to the educational system, as school maintenance and operation was reorganized under the Klebelsberg Institutional Maintenance Centre (KIMC). Concomitantly, with generously supporting the Christian churches to take over schools, the rate of pupils in parochial schools increased significantly, while the rate of pupils in public schools decreased. The number of parochial schools primarily rose in elementary education, and especially in the poorer regions of the country and in smaller settlements. This also indicates that Roma pupils are increasingly educated in certain parochial schools. The newly founded parochial schools of historical churches are supported by the state budget, and they exacerbated local segregation processes. Ercse (2018) called this phenomenon state-motivated church-assisted segregation.

In 2011, the National Social Inclusion Strategy (2011-2020) came into force which aimed at improving the living conditions of the Roma and those in general who live in extreme poverty and child poverty. This strategy also embraces various scholarships (Útravaló Scholarship Program, János Arany Gifted and Talented Program, János Arany College Program, János Arany College and Vocational School Program) and extracurricular tutoring centres for social disadvantaged children ("tanoda program"-in Hungarian), as well as mentor programs for Roma students in higher education. However, one has to note that if the formal education system operated well, there wouldn't be necessary to launch such complementary programmes (see Németh et al. 2013; Németh 2009). 
In conclusion, we can state that the educational outcomes of Roma children have improved over the past decades, but this is primarily due to the structural and specific characteristics of the educational system. Roma students do increasingly complete elementary education and obtain a baccalaureate or a degree at growing rates, but compared to the whole population they are still the most disadvantaged group in education and due to the educational expansion inequalities have shifted to higher educational levels.

\section{The Role of Resilience}

The concept of resilience originally refers to the individual's capacity to cope with unexpected shocks and unpredictable situations. Originating from ecological theories, the approach has been widely applied in social sciences lately, particularly in the analysis and critic of neoliberal governance (Chandler 2015; Joseph 2015) as well as in post-9/11 security studies (Székely 2015). In the context of education, the concept has been applied to explain how disadvantaged students had overcome structural constraints and became educationally successful and socially mobile (Werner 1982; Masten 2001; Reid and Botterrill 2013; Máté 2015). However, more recent studies focusing on how neoliberal regimes worked their way into governments, the operation of organizations and the lives of ordinary people have broadened the scope of inquiry to organizations and communities (for an exciting social historical application, see Majtényi 2015). Hall and Lamont (2013) argue that institutional and cultural changes greatly structure the contexts in which people live; their self-concepts, orders of worth and criteria of evaluation are deeply linked to the changing dynamics of inclusion and exclusion in society (see also Albert-Lôrincz and Albert-Lórincz 2015).

We define community resilience as the self-organization of groups of people into organizations, classes, ethnic groups, communities, which helps them to preserve their well-being and cope with environmental challenges (Hall and Lamont 2013). Although individuals need a certain amount of internal psychological strength to overcome obstacles, we aim to focus at the institutional, cultural and social sources of resilience (Hall and Lamont 2013, pp. 2-3), more specifically, at the local configurations of resilience in school-community relations (for a similar analysis in the social sector see Dániel and Deák 2015). Within this strand of the literature, we have been particularly inspired by researches that apply the concept to organizational and community settings and inquire the community social resources/capital mobilized in order to tackle, adapt, resist neoliberal change. Studies that explore the ways in which neoliberal hegemonic reforms and discourses may be subverted or may be innovatively capitalized on by using them for anti-neoliberal purposes have particularly shaped our thinking (e.g. Kymlicka 2013). Our interest is much similar to the perspective of Hertzman and Siddiqi (2013) who, by examining "trend-bucker" communities in Canada, inquired how local communities succeed in promoting young children's development when public provision and governmental 
programmes have failed to provide sufficient support. Our interest in coping strategies during the radical social and public sector restructurings in Hungary after the economic crisis has also gained inspiration from the literature about the effects of and responses to austerity policies in the public sector and about the transition from welfare to workfare policy regimes (Clarke and Newman 2012).

Examining educational resilience in a multi-cultural environment, Morales and Trotman (2004) emphasized the importance of environmental factors such as the institutionalized contact between schools and families (e.g. tutoring, the presence of other developmental activities) as well as other less formal community programmes. Masten et al. (1990) identify three local characteristics that impact on the development of resilient children: (1) the availability of social organizations that provide an array of resources for resilient students; (2) the consistent expressions of social norms so that community members understand what constitutes desirable behaviour and attitudes; (3) opportunities for children to participate in the life of the community as valued members. Although our research project concentrates on communityschool interactions as well, the following analysis focuses on the conditions of institutional resilience in particular.

\section{Hypothesis, Research Questions and First Results}

By using the dataset of the NABC, we created a typology of resilient, 'ordinary' schools and 'irresilient' or elementary schools at risk (see below), and we have formulated three main hypotheses:

(a) Effective and resilient schools are more likely to be found in smaller settlements because the effect of school choice on social segregation is greater in bigger settlements. Irresilient schools or schools at risk are more likely to be located in urban environments.

(b) If the social economic status (SES) index of schools is under statistical control, the correlation between the estimated rate of Roma students and the schools' 'resilience' typology status will not be statistically significant.

(c) Resilient schools are more likely to have participated in innovative pedagogic programmes than 'irresilient' schools.

We define resilient schools as schools that significantly overperform in comparison to schools with similar social intakes. Irresilient schools are identified by being underperforming in comparison to schools with similar social intakes. The school types were created by correlating the socio-economic status index (SES) and the success index of the schools (SIS). The socio-economic status index (SES) is an aggregated standardized variable combining statistical variables which reflect parents' education and the possession of material goods. The success index of schools 
Table 6.2 School types by the students' family background and level of achievement

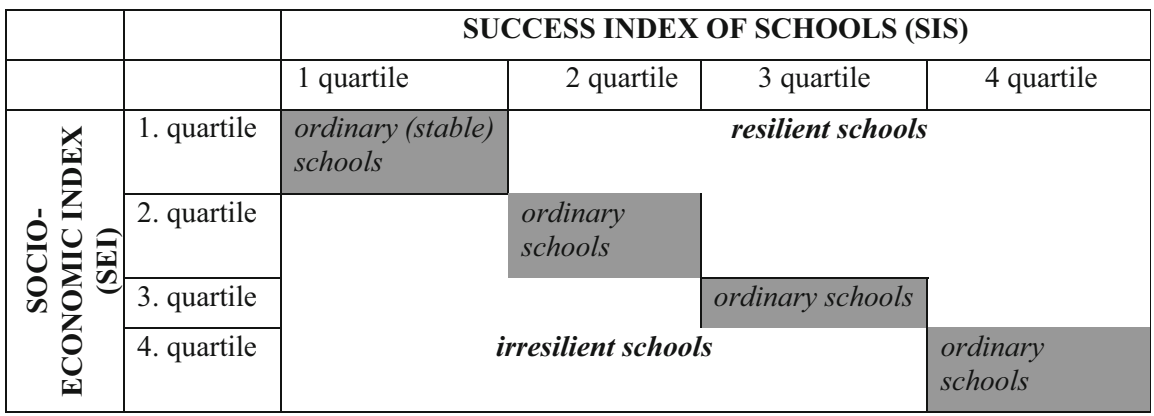

(SIS) — for the sake of the current analysis—is defined by the schools' overall performance. ${ }^{3}$

By using these two dimensions (SES and SIS), we identified resilient schools (effective, overperforming and successful schools according to the estimated SES). We also identified ordinary schools and irresilient schools or schools at risk (low SIS and underperforming schools according to the estimated SES).

Since institutional resilience is a multifaceted phenomenon, we aimed at capturing this complexity statistically. Going beyond the international standard calculation procedures, we differentiated between three types of resilient schools (see Table 6.2):

1. irresilient schools (schools at risk): underperforming schools;

2. ordinary schools: schools with expected performance;

3. resilient schools: overperforming schools.

\section{First Results}

In our calculations to test the hypotheses discussed above, we used the NABC database from 2013. First, we identified resilient schools, and then we compared resilient and irresilient schools. The statistical comparison of these two school types covers the dimensions available in the NABC database such as student social background, school climate, some settlement factors, features of school infrastructure, teacher characteristics and teacher activities.

Strictly speaking only $0.9 \%$ of all Hungarian schools can be identified as resilient (fourth quartile of performance and low SES index). Therefore, based on statistical considerations, we expanded the group of resilient schools by including all schools

\footnotetext{
${ }^{3}$ It is worth noting that we are aware of that a comprehensive SIS index should combine school performance measures, school marks which impact further study choices, secondary entrance exam results, entry rates to academic secondary pathways, and a school-level student motivation index.
} 
performing above expected. However, in order to keep socio-economic background under control we only concentrated on resilient schools whose social intake falls into the lowest quartile of the SES index. Thus, we could compare schools with very similar socio-economic background. Another consideration that led us to constrain the analysis to this group was that this was the group with the highest Roma ratio, $33 \%$ (while it is $14 \%$ in the whole school population). It was theoretically easier to grasp the role of multiethnicity within this group than in the whole school system.

We analysed the effect of different factors in making ordinary schools to become resilient by using a multivariate statistical model based on logistic regression (see Table 6.3). Coefficients in the last column of Table 6.3 indicate the odds ratio of certain factors which may have influence on school resilience. The dependent variable of the model is a dummy variable which indicates the resilience category of a school ( 0 -ordinary school; 1 -resilient school). Factors included in the model explain the variance of school resilience in approximately 39\%. Based on our statistical model, we can conclude that when keeping the effect of other variables under statistical control, multi-ethnic student composition does not have a significant statistical impact on school resilience. In turn, student socio-economic status (SES) does have a significant effect on school effectiveness, which is well-marked taking into consideration that the model only concerns the narrowed student population, that is, students or schools at the lowest quartile of the SES index. School climate also plays a significant effect, however the odds ratios in this case is quite low. We observed a somewhat positive correlation with discipline and negative impact of student motivation on school performance. The moderate negative impact of motivation on school performance which may contradicts common sense is actually not surprising: international assessments have also highlighted recently that student motivation does not necessarily have linear positive effect on school effectiveness (OECD 2016).

Settlement factors included in the database have threefold effects. First, urban schools were found to be significantly less likely to be resilient than village schools. Second, regionally speaking, the (rural or small) schools in the vicinity of Budapest seem to have a higher chance to become resilient. Moreover, resilient schools are more likely to be found where parents cannot choose between several schools in their neighbourhood. This is because where parents can choose between educational institutions, schools tend to become increasingly homogenous in terms of student social-economic background, which may affect school resilience negatively.

Amongst school environment characteristics, we should mention that school size has a positive effect: the bigger the student population, the higher the likelihood of resilient schools. While the number of computer labs also rose the likelihood of school resilience, the number of language teaching rooms decreased the likelihood of resilience. At the same time it seems that the good state of the school building increases the likelihood of resilience.

Among teacher characteristics some special activities seem to have the most powerful effect on school resilience: if teachers are active in publishing papers the chance of a school resilience is lower. In other words, the data suggest that in resilient schools, teachers mainly concentrate on teaching and not publishing. In 
Table 6.3 Factors pushing ,stable” schools to resilience (logistic regression, Nagelkerke R: 0.388)

\begin{tabular}{|c|c|c|c|}
\hline & & Sig. & $\operatorname{Exp}(\mathrm{B})$ \\
\hline \multirow[t]{2}{*}{ Student } & $\%$ Roma & 0.401 & 0.998 \\
\hline & SES & 0.000 & $2.940 *$ \\
\hline \multirow[t]{2}{*}{ School climate } & Discipline & 0.000 & $1.100 *$ \\
\hline & Motivation & 0.000 & $0.922 *$ \\
\hline \multirow[t]{15}{*}{ Settlement factors } & Type of settlement (ref. categ: Village) & 0.000 & \\
\hline & Small city & 0.054 & 0.528 \\
\hline & Bigger city & 0.000 & $0.252 *$ \\
\hline & Budapest & 0.002 & $0.349 *$ \\
\hline & $\begin{array}{l}\text { School location inside the settlement }(1 \text { - central area; } \\
2 \text { - periphery) }\end{array}$ & 0.033 & $0.834 *$ \\
\hline & Region (ref. categ: Budapest) & 0.000 & \\
\hline & Central & 0.997 & 0.999 \\
\hline & Central-Transdanubian & 0.000 & $0.293 *$ \\
\hline & West-Transdanubian & 0.010 & $0.637 *$ \\
\hline & South-Transdanubian & 0.000 & $0.403 *$ \\
\hline & Northern & 0.000 & $0.127 *$ \\
\hline & East-Northern & 0.000 & $0.192 *$ \\
\hline & School-choice possibility (ref. categ: No choice) & 0.000 & \\
\hline & At least two other schools & 0.188 & 0.921 \\
\hline & Only one other school & 0.000 & $0.731 *$ \\
\hline \multirow{15}{*}{$\begin{array}{l}\text { School } \\
\text { infrastructure }\end{array}$} & School size & 0.000 & $1.297 *$ \\
\hline & Year of school building & 0.000 & $0.995 *$ \\
\hline & State of school building (1-very good); 5—very bad) & 0.000 & $0.543 *$ \\
\hline & No. of classroom & 0.000 & $0.946 *$ \\
\hline & No. of lang. teaching labs & 0.000 & $0.648 *$ \\
\hline & No. of special classroom & 0.000 & $0.947 *$ \\
\hline & No. of computer labs & 0.000 & $1.554 *$ \\
\hline & Other labs (szükségtanterem) & 0.130 & 0.967 \\
\hline & No. of gyms & 0.209 & 1.082 \\
\hline & Development rooms & 0.000 & $1.670 *$ \\
\hline & Number of $0-3$ years computers & 0.123 & 0.996 \\
\hline & Number of $4-5$ years computers & 0.116 & 1.005 \\
\hline & Number of 5 years older computer & 0.000 & $0.989 *$ \\
\hline & Number of computers connected to internet & 0.555 & 1.002 \\
\hline & Book titles in school library & 0.000 & $1.000 *$ \\
\hline \multirow{8}{*}{$\begin{array}{l}\text { Teacher } \\
\text { characteristics }\end{array}$} & New teachers (hired after 2011) & 0.000 & $0.824 *$ \\
\hline & Teacher: Publish articles $(1-y e s ; 2-n o)$ & 0.000 & $3.466^{*}$ \\
\hline & Teacher: Part. In manual writing $(1-y e s ; 2-n o)$ & 0.956 & 1.008 \\
\hline & Teacher: Member of professional org. $(1-y e s ; 2-n o)$ & 0.569 & 1.048 \\
\hline & Teacher: Member of civil organizations (1-yes; $2-n o)$ & 0.210 & 0.921 \\
\hline & Teacher: Mother tongue other than HU (1-yes; 2-no) & 0.007 & $0.683 *$ \\
\hline & Teacher: Non HU citizen $(1-y e s ; 2-n o)$ & 0.004 & $1.740 *$ \\
\hline & Teacher: Roma origin $(1-y e s ; 2-n o)$ & 0.000 & $0.643^{*}$ \\
\hline
\end{tabular}


Table 6.3 (continued)

\begin{tabular}{|c|c|c|c|}
\hline & & Sig. & $\operatorname{Exp}(B)$ \\
\hline \multirow[t]{5}{*}{ Teacher activity } & In-service training_-discipline based & 0.000 & $1.034 *$ \\
\hline & In-service training for leaders of schools & 0.113 & 1.040 \\
\hline & Personality development training & 0.010 & $1.007 *$ \\
\hline & In-service training: Assessment & 0.000 & $1.094 *$ \\
\hline & In-service training: Other & 0.000 & $0.980 *$ \\
\hline \multirow[t]{10}{*}{ School activity } & Evaluation: head's observations (1-yes; $2-$ no) & 0.997 & 0.000 \\
\hline & Evaluation: maintainer's observations (1-yes; $2-n o)$ & 0.003 & $0.833 *$ \\
\hline & Evaluation: External experts $(1-$ yes; $2-n o)$ & 0.303 & 0.938 \\
\hline & Evaluation: Colleagues' observations $(1-$ yes; $2-n o)$ & 0.000 & $0.283 *$ \\
\hline & Evaluation: Students' results (1-yes; $2-$ no) & 0.636 & 0.953 \\
\hline & Selection during student enrollment $(1-$ yes; $2-n o)$ & 0.407 & 1.071 \\
\hline & $\begin{array}{l}\text { School program: Integrational, development program } \\
(1-\text { yes; } 2-n o)\end{array}$ & 0.822 & 0.985 \\
\hline & $\begin{array}{l}\text { School program: Gipsy nationality program }(1-y e s ; 2- \\
\text { no) }\end{array}$ & 0.000 & $1.364^{*}$ \\
\hline & Constant & 0.995 & $\begin{array}{l}1.677 \mathrm{E} \\
+14\end{array}$ \\
\hline & Nagelkerke R-square & & 0.388 \\
\hline
\end{tabular}

*Statistically significant effect

the framework of our research, we were especially interested in whether the ethnic composition of the local teacher community would have a statistical effect on school resilience. Schools that employs teachers with Roma background or with a mother tongue other than Hungarian are more likely to be successful. Interestingly, employing teachers with foreign citizenship decreases the likelihood of resiliency. Although this latter fact seems to contradict our hypothesis about the beneficial effect of the inner multiethnicity of the teaching body, we think that this is because the "foreign citizenship" category often refers to people with Hungarian background who were born in neighbouring countries and who do not hold Hungarian citizenship. Thus, we can conclude that the "real inner multiethnicity" of the teacher community could have a positive impact on school success.

Two school-related development programmes had a significant correlation with school resilience. The so-called "Gypsy nationality" programme seems to have a negative effect on school performance, while the external control of teachers carried out by colleagues or authorities suggests a positive one. We argue that the negative effect of the "Gypsy nationality" programme is due to the fact that these

\footnotetext{
${ }^{4}$ The "Nationality (minority) education" programme can be organized in several different forms: (1) mother-tongue education; (2) bilingual education; (3) language teaching minority education; (4) Roma/Gypsy minority education in Hungarian language; (5) and auxiliary minority education. https://net.jogtar.hu/jr/gen/hjegy_doc.cgi?docid=a1300017.emm
} 
Table 6.4 Variance of resilience explained by student, settlement and school related factors

\begin{tabular}{l|l|l}
\hline Factors & $\begin{array}{l}\text { Nagelkerke R-square } \\
\text { (variance explained by } \\
\text { factors) }\end{array}$ & Observation \\
\hline $\begin{array}{l}\text { Student related factors: SRF (SES, } \\
\% \text { Roma) }\end{array}$ & $\mathbf{0 . 0 8 3}$ & \\
\hline SRF + school climate & $\mathbf{0 . 0 8 8}$ & \\
\hline $\begin{array}{l}\text { SRF + school climate + settlement } \\
\text { factors }\end{array}$ & $\mathbf{0 . 1 0 5}$ & \\
\hline $\begin{array}{l}\text { SRF + school climate + settlement } \\
\text { factors+school structural features }\end{array}$ & $\mathbf{0 . 2 7 9}$ & $\begin{array}{l}\text { Positive role of Roma and } \\
\text { non-Hungarian teachers on } \\
\text { resilience }\end{array}$ \\
\hline $\begin{array}{l}\text { SRF + school climate + settlement } \\
\text { factors + school structural features } \\
+ \text { teacher characteristics, practicies }\end{array}$ & $\mathbf{0 . 3 6 3}$ & $\begin{array}{l}\text { Roma student \% effect on } \\
\text { resilience has disappeared }\end{array}$ \\
\cline { 2 - 3 } $\begin{array}{l}\text { SRF + school climate + settlement } \\
\text { factors + school structural features } \\
+ \text { teacher characteristics, practicies } \\
+ \text { schools' activity }\end{array}$ & $\mathbf{0 . 3 8 8}$ & Role of SES \\
\hline
\end{tabular}

programmes are mostly run in Hungarian language, and their aim is to broaden the students' knowledge about Roma tradition and history. This is why these types of school programmes have no impact on reading or mathematics competences measured in the national tests. ${ }^{5}$ The positive effect of external teacher professional control carried out by educational authorities or other teachers suggests that teacher effectiveness in Hungary can be raised by the external presence of other persons. We explain this with historical or pedagogical reasons; however, it suggests the necessity of feedback during the teaching process.

Factors included in the model explain the variance of school resilience in approximately 39\%. However we should consider the level of cumulative impact too. According to Table 6.4 we can conclude that while student and settlement related factors only explain resilience in $8-10 \%$, the effect of pedagogical work should be much greater. We argue that in spite of the fact that territorial or community characteristics could have significant effects in some instances, school and teacher activities matter most in school resilience.

\footnotetext{
${ }^{5}$ In an absolutely different context an official report of the Gypsy nationality programmes argues that this type of programme is not effective as it concentrates students with Roma background and with social disadvantages, and it also implies a selection among children at techer level. Teachers working in this type of programme cannot cope with these challenges. See Jelentés... 2014.
} 


\section{Conclusions}

In this chapter we presented basic information concerning Roma education in Hungary, and some elements of a theoretical framework which aims to identify the main factors of school resilience in Hungary. Our core question concerned internal institutional and external school factors that can contribute to educational resilience.

We presented the first results based on the statistical analysis of the 2013 NABC database with particular focus on institutional factors. ${ }^{6}$ Firstly we created a school typology, and then we tried to test some basic hypothesis. According to our first hypothesis effective and resilient schools are more likely to be found in smaller settlements because the effect of school choice on social segregation is greater in bigger settlements. We found that resilient schools are more likely to be located in rural areas and in localities where the school-choice options are more restricted. Moreover, a slight effect of the capital was observed: resilient schools tended to be located in the broad suburbs of the capital of the country, and not in regions where there is a higher Roma intake in schools (Northern, Northern-Easter Hungary).

With regard to the second hypothesis we expected that-if the social economic status index (SES) of schools is under statistical control-the correlation between the estimated rate of Roma student and the 'resilience' status of the schools will not be statistically significant. The hypothesis was partially confirmed. If the explanation model excludes teacher and school characteristics and only focuses on student background and regional aspects, one can observe that the estimated Roma student ratio has a negative effect on resilience: the higher the rate of Roma students the higher the likelihood of a school to be irresilient. However, in this case the model has a low explanatory strength. When the model was complemented with teacher and school related factors, the significant effect of Roma intake disappeared, and we could see that the multiethnicity of the staff and some other factors could push schools towards resiliency.

The third hypothesis concerned the role of school programmes. Our hypothesis was that resilient schools are more likely to have been involved in innovative pedagogic programmes than 'irresilient' schools. This hypothesis was not confirmed. According to the model, participation in local or nation-wide innovative pedagogic programmes (focusing on integrated education and professional development) had no statistically significant effect on the resiliency status of the schools. Moreover, we also found that the "Gypsy nationality" programme had a negative impact. This can be explained by the fact that this type of minority-centred school programme did not focus on the development of participating children's skills and (reading and mathematics) competences.

It is difficult to formulate complex policy implications at this point of the study, not having completed the analysis of the qualitative case studies in resilient schools.

\footnotetext{
${ }^{6}$ It is worthwhile to mention that this quantitative analysis is based on NABC database administered in the $2012 / 2013$ school year. Future analysis will explore whether these statistical patterns prevail over the years.
} 
However, it was striking how few low SES schools fell into the resilient category. If policymakers aim to improve the educational level of Roma students, multi-ethnic and segregated schools, good practices of resilient low SES schools should be closely analysed and upscaled and the teaching staff of these schools should be rewarded both financially and symbolically. In fact, by using the results of NABC in Hungary there is an opportunity to design systemic implications in order to narrow social and regional inequalities of education, and to foster the school success of Roma children.

\section{References}

Albert-Lốrincz, E., \& Albert-Lőrincz, C. (2015). Szimbólumokba és narratívákba rejtett közösségi rezilienciajegyek—segítók percepciójában. Erdélyi Társadalom, 13(1), 87-100.

Chandler, D. (2015). A neoliberalizmuson túl: reziliencia, a komplexitás kormányzásának új módja. Replika, 95, 25-44.

Clarke, J., \& Newman, J. (2012). The alchemy of austerity. Critical Social Policy, 32(3), 299-319.

Clotfelter, C. T. (2006). After Brown. The rise and retreat of school desegregation. Princeton: Princeton University Press.

Creemers, B., Kyriakides, L., Panayioutu, A., Bos, W., Holtappels, H. G., Pfeifer, M., \& Tempridou, A. (2013). Establishing a knowledge base for quality in education: Testing a dynamic theory for education. Handbook on designing evidence-based strategies and actions to promote quality in education. Münster, New York, München, Berlin: Waxman.

Dániel, B., \& Deák, E. (2015). A helyi szociális háló vizsgálata a közösségi reziliencia szemszögéból Gyergyószentmiklóson. Erdélyi Társadalom, 13(1), 21-42.

Durst, J., Fejôs, A., \& Nyírő, Zs. (2016). "Másoknak ez munka, nekem szívügyem”. Az etnicitás szerepe a diplomás roma nók munka-család konstrukcióinak alakulásában. SOCIO.HU, 2016/2. doi: https://doi.org/10.18030/socio.hu.2016.2.198.

Ercse, K. (2018). Az állam által ösztönzött, egyházasszisztált szegregáció mechanizmusa. In J. B. Fejes \& N. Szúcs (Eds.), Én vétkem. Helyzetkép az oktatási szegregációról (pp. 177-200). Szeged: Motiváció Oktatási Egyesület.

Erôs, G. (2012). Iskolai (dez)integrációs paradoxonok: expanzió, integráció, szegregáció a magyar közoktatásban a rendszerváltás óta. In I. Kovách, C. S. Dupcsik, P. T. Tóth, \& J. Takács (Eds.), Társadalmi integráció a jelenkori Magyarországon (pp. 262-274). Argumentum: Budapest.

Feischmidt, M. (2013). A szegregáció folyománya: kortárs és tanár-diák kapcsolatok Európa multietnikus iskolai közösségeiben. Esély, 2, 53-69.

Hall, P. A., \& Lamont, M. (2013). Introduction. In P. A. Hall \& M. Lamont (Eds.), Social resilience in the neoliberal era (pp. 1-31). Cambridge University Press: Cambridge.

Havas, G. (2008). Esélyegyenlőség, deszegregáció. In K. Fazekas, J. Köllő, \& J. Varga (Eds.), Zöld Könyv. A magyar közoktatás megújitásáért (pp. 121-138). Budapest: ECOSTAT.

Hertzman, C., \& Siddiqi, A. (2013). Can communities succeed when states fail them? A case study of early human development and social resilience in a neoliberal era. In P. A. Hall \& M. Lamont (Eds.), Social resilience in the neoliberal era (pp. 293-318). Cambridge: Cambridge University Press.

Jencks, C., Smith, M., Acland, H., Bane, M. J., Cohen, D., Gintis, H., Heyns, B., \& Michelson, S. (1972). Inequality: A reassessment of the effects of family and schooling in America. New York: Basic Books.

Joseph, J. (2015). A neoliberalizmuson túl: reziliencia, a komplexitás kormányzásának új módja. Replika, 95, 45-61. 
Kertesi, G. (2005). A társadalom peremén. Romák a munkaerópiacon és az iskolában. Budapest: Osiris.

Kertesi, G., \& Kézdi, G. (2011). The Roma/non-Roma test score gap in Hungary. American Economic Review, 101(3), 519-525.

Kézdi, G., \& Surányi, É. (2009). Egy integrációs program hatása a tanulók fejlődésére. Education, 18(4), 467-479.

Kovács, K. (2012). Rescuing a Small Village School in the Context of rural change. Journal of Rural Studies, 28(2), 108-117.

Kymlicka, W. (2013). Neoliberal Multiculturalism? In P. A. Hall \& M. Lamont (Eds.), Social resilience in the neoliberal era (pp. 99-125). Cambridge: Cambridge University Press.

Majtényi, G. (2015). "De elmehet a Kádár Jani a picsába!” Reziliencia az államszocializmusban. Replika, 95, 95-112.

Masten, A. S. (2001). Ordinary magic. Resilience processes in development. American Psychologist, 56(3), 227-238.

Masten, A., Best, K., \& Garmezy, N. (1990). Resilience and development: Contributions from the study of children who overcome adversity. Development and Psychopatology, 2, 425-444.

Máté, D. (2015). Reziliens romák identitáskonstrukciói. Erdélyi Társadalom, 13(1), 43-55.

Morales, E. E., \& Trotman, F. K. (2004). Promoting academic resilience in multicultural America. Factors affecting student success. New York: Peter Lang Publishing, New York.

Mourshed, M., Chijioke, C., \& Barber, M. (2010). How the world's most improved school systems keep getting better. London: McKinsey\&Co. Retrieved from http://mckinseyonsociety.com/ downloads/reports/Education/How-the-Worlds-Most-Improved-School-Systems-Keep-Get ting-Better_Download-version_Final.pdf.

Németh, S. (Ed.). (2009). A tanoda-típusú intézmények múködésének, tevékenységének elemzése. Kutatási jelentés. Budapest: T-Tudok. Retrieved from http://www.tarki-tudok.hu/file/ tanulmanyok/tanodaelemzes.pdf.

Németh, S., \& Papp, Z. A. (2006). És mi adjuk az integráció vezérfonalát. In S. Németh (Ed.), Integráció a gyakorlatban. A roma tanulók együttnevelésének iskolai modelljei (pp. 9-30). Budapest: OKI. Retrieved from http://ofi.hu/tudastar/hatranyos-helyzet/integraciogyakorlatban.

Németh, S., Lannert, J., \& Zágon, M. (2013). Tanodakutatás és Fejlesztés 2012/2013. Roma Oktatási Alap, Budapest: Zárótanulmány. Retrieved from http://www.romaeducationfund.hu/ sites/default/files/publications/tanoda-projekt_zarobeszamolo_2013nov_.pdf.

Neumann, E. (2013). Politika a padsorok közt. In E. Berényi, G. Erôss, \& E. Neumann (Eds.), Tudás és Politika. Budapest: L'Harmattan.

OECD. (2010a). PISA 2009 results: Overcoming social background-Equity in learning opportunities and outcomes (Vol. II). Retrieved from https://doi.org/10.1787/9789264091504-en

OECD. (2010b). PISA 2009 results: What makes a school successful?-Resources, policies and practices (Vol. IV). Retrieved from https://doi.org/10.1787/9789264091559-en

OECD. (2016). PISA 2015 results (Vol. I): Excellence and equity in education, PISA. Paris: OECD Publishing. Retrieved from https://doi.org/10.1787/9789264266490-en.

Papp, Z. A. (2011). A roma tanulók aránya Magyarországon és a tanulói teljesítmények az általános iskolai oktatásban. In N. Bárdi \& Á. Tóth (Eds.), Asszimiláció, integráció, szegregáció. Párhuzamos értelmezések és modellek a kisebbségkutatásban (pp. 227-264). Budapest: Argumentum.

Papp, Z. A. (2013). Pedagógiai hozzáadott érték a roma tanulói arány függvényében a magyar iskolarendszerben. In N. Bárdi \& Á. Tóth (Eds.), Önazonosság és tagoltság: Elemzések a kulturális megosztottságról (pp. 69-88). Budapest: Argumentum.

Radó P. (1997). A nemzeti és etnikai kisebbségek oktatása. (A Jelentés a magyar közoktatásról 1997 kötet háttértanulmánya). Retrieved from http://www.ofi.hu/tudastar/jelentes-magyar/nemzetietnikai

Reid, R., \& Botterrill, L. C. (2013). The multiple meanings of 'resilience': An overview of the literature. Australian Journal of Public Administration, 72(1), 31-40. 
Sammons, P. (2007). School effectiveness and equity: Making connections. Reading: CfBT Education Trust. Retrieved from http://www.cfbt.com/evidenceforeducation/pdf/Full\%20Literature $\% 20$ Review.pdf.

Sammons, P., \& Reynolds, D. (1997). A partisan evaluation - John Elliott on school effectiveness. Cambridge Journal of Education, 27(1), 123-136.

Scheerens, J., \& Bosker, R. (1997). The foundations of educational effectiveness. Oxford: Pergamon.

Szalai, J., \& Schiff, C. (Eds.). (2014). Migrant, Roma and post-colonial youth in education across Europe. Being 'visibly different'. Macmillan: Palgrave.

Székely, I. (2015). Reziliencia: a rendszerelmélettól a társadalomtudományokig. Replika, 95, 7-23.

Teddlie, C., \& Reynolds, D. (2000). The international handbook of school effectiveness research. London: Falmer.

Tóth, K. D. (2008). Sikeres cigányok identitása Angliában és Magyarországon. Budapest: L'Harmattan.

Vidra, Z. (2012). Kistérségi közoktatás a Nagykállói kistérségben. In É. Balázs \& K. Kovács (Eds.), Többcélú küzdelem (pp. 275-307). Budapest: OFI.

Virág, T. (2012). A sötét Abaújtól most leghátrányosabb, ennyi az elốrelépésünk .... In É. Balázs \& K. Kovács (Eds.), Többcélú küzdelem (pp. 243-274). Budapest: OFI.

Werner, E. E. (1982). Vulnerable but invincible: A longitudinal study of resilient children and youth. New York: McGraw-Hill.

Open Access This chapter is licensed under the terms of the Creative Commons Attribution 4.0 International License (http://creativecommons.org/licenses/by/4.0/), which permits use, sharing, adaptation, distribution and reproduction in any medium or format, as long as you give appropriate credit to the original author(s) and the source, provide a link to the Creative Commons licence and indicate if changes were made.

The images or other third party material in this chapter are included in the chapter's Creative Commons licence, unless indicated otherwise in a credit line to the material. If material is not included in the chapter's Creative Commons licence and your intended use is not permitted by statutory regulation or exceeds the permitted use, you will need to obtain permission directly from the copyright holder.

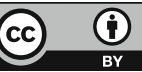

